\title{
Spekulatif Arah Politik Hukum Kepariwisataan Di Indonesia Dari Pengembangan Community Base Tourism
}

\author{
Dhoni Martein ${ }^{1}$, Dhian Tyas Untari ${ }^{2, *}$, Desyana Berliana ${ }^{1}$, Iswiyati Kunti ${ }^{1}$, Tiara Yuliana \\ Wanti ${ }^{1}$, Wiky Rikamza ${ }^{1}$ \\ ${ }^{1}$ Fakultas IImu Hukum; Universitas Jayabaya; Jl. Pulomas Selatan Kav. No.23, RT.4/RW.9, \\ Kayu Putih, Kec. Pulo Gadung, Kota Jakarta Timur, Daerah Khusus Ibukota Jakarta, Tlp. (021) \\ 4700874; e-mail:dhonimartien75@gmail.com, desyanaberliana@gmail.com, \\ iswiedogawa@gmail.com, wtiaray@gmail.com, wrikamza@gmail.com \\ 2 Fakultas Ekonomi dan Bisnis; Universitas Bhayangkara Jakarta Raya; JI Perjuangan 081, \\ Marga Mulya, Bekasi Utara, 02188955882/ +622188955871; e-mail: \\ dhian.tyas@dsn.ubharajaya.ac.id
}

* Korespondensi: e-mail: dhian.tyas@dsn.ubharajaya.ac.id

Submitted: 15/12/2021; Revised: 18/12/2021; Accepted: 28/12/2021; Published: 31/12/2021

\begin{abstract}
Tourism is a non-oil and gas sector with a fairly high development potential, even the tourism sector makes a large contribution to GDP and GRDP. According to the Law of the Republic of Indonesia Number 10 of 2009 concerning Tourism and the Regulation of the Minister of Home Affairs Number 33 of 2009 concerning Guidelines for Ecotourism Development in the Regions, it is stated the importance of community participation in tourism development. Based on this, this study aims to; 1). Studying the political direction of tourism law in Indonesia, 2). Mapping the internal and external environment for Community Base Tourism (CBT) development, and 3). Develop speculative hypotheses related to the CBT development strategy. This study is sourced from secondary data from books and publications related to Tourism Law Politics and CBT Development. The analysis used is the Strategic Management matrix; EFAS/IFAS and Garnd Matrix. The results of the study are expected to become an umbrella for research related to the development of CBT in the perspective of Political Law.
\end{abstract}

Keywords: Community Base Tourism, Legal politics, Tourism

\begin{abstract}
Abstrak
Pariwisata merupakan sektor non migas dengan potensi pengembangan yang cukup tinggi bahkan sektor Pariwisata memberikan kontribusi yang besar dalam PDB dan PDRB. Menurut Undang-Undang Republik Indonesia Nomer 10 tahun 2009 tentang Kepariwisataan dan Peraturan Menteri Dalam Negeri Nomor 33 Tahun 2009 tentang Pedoman Pengembangan Ekowisata di Daerah disebutkan pentingnya keikutsertaan masyarakat dalam pengembangan wisata. Berdasarkan hal tersebut maka kajian ini bertujuan untuk; 1). Mengkaji arah politik hukum kepariwisataan di Indonesia, 2). Memetakan lingkungan internal dan external pengembangan Community Base Tourism (CBT), dan 3). Menyusun hipotesis spekulatif terkait strategi pengembangan CBT. Kajian ini bersumber dari data skunder yang berasal dari buku dan publikasi terkait Politik Hukum Kepariwisataan dan Pengembangan CBT. Analisis yang digunakan adalah matrik Manajemen Strategi; EFAS/IFAS dan Garnd Matriks. Hasil kajian diharapkan padat menjadi payung bagi penelitian terkait pengembangan CBT dalam perspektif Politik Hukum.
\end{abstract}

Kata kunci: Community Base Tourism, Politik hukum, Kepariwisataan 
Dhoni Martein, Dhian Tyas Untari, Desyana Berliana, Iswiyati Kunti, Tiara Yuliana Wanti, Wiky Rikamza

\section{Pendahuluan}

Di Indonesia sektor wisata merupakan salah satu penyumbang devisa yang signifikan bagi Indonesia. Secara keseluruhan, sektor pariwisata menjadi penyumbang no 5 pada tahun 2008, no 4 pada tahun 2009 dan no 5 pada tahun 2010. Jika dilihat sumbangan sektor non migas, sektor pariwisata menempati urutan 2 dan 3 (Dewi , 2011). Sektor pariwisata merupakan salah satu sektor penyumbang devisa terbesar setelah migas. Sektor pariwisata juga merupakan salah satu sektor pembangunan yang mempunyai manfaat ganda atau multiplier effect secara ekonomi bagi pemerintah daerah melalui peningkatan Pendapatan Asli Daerah (PAD) dan ekonomi masyarakat melalui perluasan kesempatan kerja dan peningkatan pendapatan (Dhian, 2019; Martaleni et al, 2021)

Perkembangan wisata secara umum membawa dampak ganda bagi lingkungan dan masyarakat. Pengambangan wisata secara konvensional seringkali membawa dampak negatef bagi lingkungan dan budaya masyarakat (Postma and Schmuecker, 2017). Dampak ekologi seperti alih fungsi lahan, gangguan terhadap habitat beberapa flora dan fauna akibat pembangunan fisik wisata serta pergeseran budaya masyarakat (Comerio and Strozzi, 2018). Masuknya budaya dari luar yang menjadi konsekuensi dari kedatangan wisatawan memberikan pengaruh bagi eksistensi budaya asal. Ketidakmampuan masyarakat dalam menyaring nilainilai budaya dan prilaku etnosentrisme menggiring tergerusnya nilai budaya asal (Stock, 2007). Selain dampak negative, pengembangan wisata juga memberikan dampak positive berupa peningkatan perekonomian masyarakat yang diikuti dengan peningkatan kesejahteraan (Zaen and Zaen, 2013).

Aturan terkait oprsionalisasi bidang Kepariwisataan ini diatur dalam Undang-Undang Republik Indonesia Nomer 10 tahun 2009 tentang Kepariwisataan Pada Bab II Pasal 4 menyebutkan bahwa Kepariwisataan bertujuan untuk meningkatkan pertumbuhan ekonomi, meningkatkan kesejahteraan rakyat, menghapus kemiskinan, mengatasi pengangguran, melestarikan alam lingkungan dan sumber daya dan memajukan kebudayaan. Dan diperkuat dengan Peraturan Menteri Dalam Negeri Nomor 33 Tahun 2009 tentang Pedoman Pengembangan Ekowisata di Daerah yang menyebutkan bahwa pengembangan ekowisata wajib memberdayakan masyarakat setempat. Hal ini sesuai dengan prinsip ekowisata yaitu peran aktif masyarakat sekitar dalam kegiatan perencanaan, pemanfaatan, dan pengendalian ekowisata dengan menghormati nilai-nilai sosial-budaya dan keagamaan masyarakat di sekitar kawasan wisata.

Pengembangan pariwisata semaksimal mungkin melibatkan masyarakat dalam pengelolaanya. Konsep Community base Tourism (CBT) digunakan oleh para perancang, pegiat pembangunan pariwisata, strategi untuk memobilisasi komunitas untuk berpartisipasi secara aktif dalam pembangunan pariwisata (Pramanik et al, 2019). Secara konseptual, prinsip dasar CBT adalah menempatkan masyarakat sebagai pelaku utama melalui pemberdayaan masyarakat dalam berbagai kegiatan kepariwisataa (Sunuantari, 2017). Sehingga, manfaat kepariwisataan sebesar-besarnya diperuntukkan bagi kesejahteraan masyarakat. Berdasarkan 
hal tersebut maka kajian ini bertujuan untuk; 1). Mengkaji arah politik hukum kepariwisataan di Indonesia, 2). Memetakan lingkungan internal dan external pengembangan Community Base Tourism (CBT), dan 3). Menyusun hipotesis spekulatif terkait strategi pengembangan CBT. Hasil kajian diharapkan padat menjadi payung bagi penelitian terkait pengembangan CBT dalam perspektif Politik Hukum.

\section{Metode Penelitian}

Objek dalam kajian ini adalah arah Politik Hukum Kepariwisataan menurut UndangUndang Republik Indonesia Nomer 10 tahun 2009 tentang Kepariwisataan dan Peraturan Menteri Dalam Negeri Nomor 33 Tahun 2009 tentang Pedoman Pengembangan Ekowisata di Daerah. Metode pendekatan yang digunakan dalam kajian adalah normative dan konseptual dimana data-data yang diperoleh bersumber dari data sekunder yang berasal dari buku dan publikasi terkait Politik Hukum Kepariwisataan dan Pengembangan CBT. Elaburasi dari sumber pustaka kemudian akan dipetakan berdasarkan kekuatan, kelemahan, peluang dan ancaman, lalu analisis lanjutan menggunakan matrik Manajemen Strategi; EFAS/IFAS dan Garnd Matriks untuk menghasilan strategi arah kebijakan yang dapat dilakukan dalam pengembangan CBT.

\section{Hasil dan Pembahasan}

\subsection{Politik Hukum Kepariwisataan di Indonesia}

United Nation World Tourism Organizations (UNWTO) mengakui bahwa sektor pariwisata adalah sektor unggulan dan merupakan salah satu kunci penting dalam pembangunan wilayah di suatu negara maupun peningkatan kesejahteraan bagi masyarakat. Meningkatnya jumlah destinasi dan investasi pariwisata menjadikan sektor pariwisata sebagai faktor kunci dalam peningkatan devisa, penciptaan lapangan kerja, pengembangan usaha dan infrastruktur.

Indonesia yang dikenal sebagai negara dengan berbagai macam potensinya mampu memikat banyak orang untuk datang dan menjelajahi keunikannya. Tak heran, pariwisata dijadikan sebagai program pembangunan prioritas yang selalu diberi target pencapaian oleh pemerintah.

Dalam lima tahun terakhir, jumlah kunjungan wisatawan mancanagera ke Indonesia terus mengalami peningkatan. Angka kunjungan ini tentunya berpengaruh terhadap pertumbuhan devisa di Indonesia. Pada tahun 2017, pariwisata Indonesia menempati urutan kedua sebagai penyumbang devisa negara setelah sektor kelapa sawit dengan nilai USD 16,8 miliar.

Industri pariwisata di Indonesia telah berkembang pesat. Dalam menciptakan iklim yang kondusif khususnya dalam pembangunan kepariwisataan, ditetapkan Undang-Undang Nomor 10 Tahun 2009 tentang Kepariwisataan (selanjutnya disebut UU Kepariwisataan) yang telah mencabut Undang-Undang Nomor 9 Tahun 1990 tentang Kepariwisataan sebagai instrumen hukum penyelenggaraan kepariwisataan. 
Dhoni Martein, Dhian Tyas Untari, Desyana Berliana, Iswiyati Kunti, Tiara Yuliana Wanti, Wiky Rikamza

Undang Nomor 10 Tahun 2009 tentang Kepariwisataan memberikan pengaturan secara menyeluruh terkait pengelolaan dan pemanfaatan potensi-potensi pariwisata yang ada di Indonesia. Pengelolaan sector Kepariwisataan juga harus memberikan dampak kesejahteraan yang sebesar-besarnya bagi rakyat Indonesia (Kurnia, 2019). Hal ini sejalan sila ke 5 dan Pembukaan Undang-Undang Dasar Negara Republik Indonesia Tahun 1945 khususnya pada Alenia keempat yang menyebutkan bahwa "melindungi segenap bangsa Indonesia dan seluruh tumpah darah Indonesia dan untuk memajukan kesejahteraan umum". Hal ini memberikan arah dan gambaran yang cukup jelas bahwa arah seluruh kebijakan termasuk terkait Kepariwisataan bertujuan untuk memberikan kesejahteraan bagi seluruh rakyat Indonesia. Made (2015) menyatakan bahwa pengembangan pariwisata bukan hanya memberikan kesejahteraan dan keadilan bagi individu, golongan atau sekelompok tertentu saja. Dalam konteks ini, tidak terkecuali pada pengelolaan sector Kepariwisataan juga harus berangkat dari perspektif perwujudan tujuan Negara kesejahteraan (Kurnia, 2019).

Indonesia kaya akan defersity baik dari budaya maupun dari ekologi alamnya. Potensi tersebut tersebar di seluruh wilayah Indonesia. Pada UU no 32 tahun 2004, tentang Pemerintahan Daerah dan UU No. 25 tahun 1999, tentang Perimbangan Keuangan Pusat dan Daerah, memberikan kewenangan untuk mengatur dan mengurus daerahnya masing-masing sesuai dengan potensi yang dimiliki oleh daerah untuk dikembangkan, hal ini merupakan konsekuensi dari pelaksanaan otonomi daerah. Sebagai konsekuensinya, untuk meningkatkan pendapatan daerah maka Pemerintah Daerah harus mampu melihat peluang dan memanfaatkannya semaksimal mungkin.

Perbedaan ekologi, geografis dan etnografi menjadi pemicu terjadinya sebuah perjalanan wisata (Dhian, 2020; Pawaskar et al, 2020). Shaw and Williams (2002) menambahkan bahwa pemahaman tentang motivasi wisatawan dan proses pengambilan keputusan adalah kunci dari keberhasilan perencanaan pariwisata.

Perencanaan pengembangan pariwisata tidak akan dapat dilepaskan dari konsep kebijakan daerah. Secara umum, istilah kebijakan digunakan untuk menunjuk perilaku seorang aktor (misalnya seorang pejabat, suatu kelompok, maupun suatu lembaga pemerintah) atau sejumlah actor dalam suatu bidang kegiatan tertentu (Winarno, 2012). Implementasi kebijakan merupakan tahapan pelaksanaan keputusan diantara pembentukan sebuah kebijakan, seperti hanya pasal-pasal sebuah undang-undang legislatif, keluarnya sebuah peraturan eksekutif dan keluarnya suatu keputusan pengadilan atau keluarnya standar peraturan dan konsekuensi dari kebijakan bagi masyarakat yang mempengaruhi beberapa aspek kehidupannya (Tahir, 2014).

Dalam Peraturan Menteri Dalam Negeri Nomor 33 Tahun 2009 tentang Pedoman Pengembangan Ekowisata di Daerah menyebutkan bahwa pengembangan ekowisata wajib memberdayakan masyarakat setempat. Hal ini sejalan dengan konsep pembangunan yang berkelanjutan (Gambar 1) dimana tiga pilar utamanya yaitu pelestarian ekologi lingkungan, peningkatan sosial budaya masyarakat dan peningkatan ekonomi (Untari et al, 2018). 


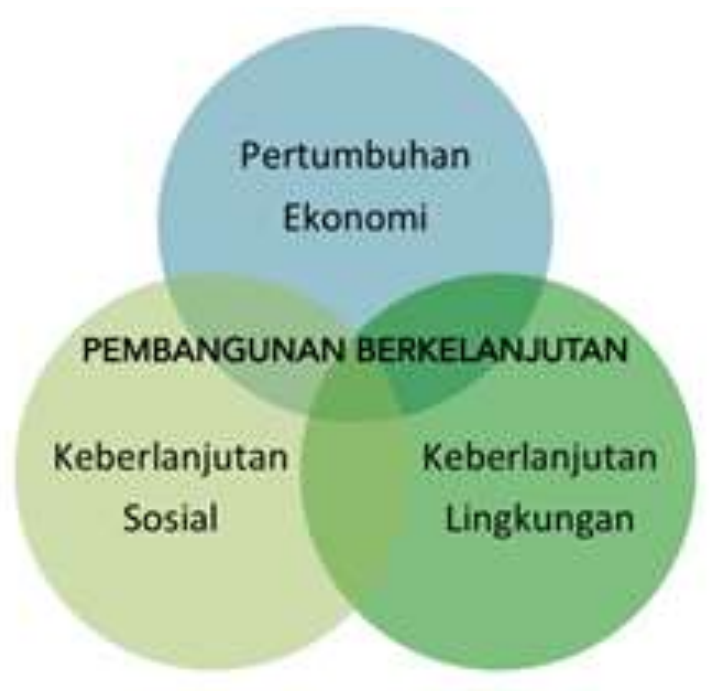

Sumber : http://www.pustakaborneo.org/

Gambar 1. Konsep Pembangunan yang Berkelanjutan

Pada konsep Pembangunan Nasional yang pada dasarnya adalah untuk mencapai pertumbuhan ekonomi dalam memenuhi kebutuhan dasar, meningkatkan standar hidup dan menciptakan lapangan kerja. Perkembangan yang pesat ditandai dengan peningkatan kemajuan di berbagai bidang, termasuk meningkatnya pembangunan di sektor industri yang pada gilirannya memberikan dampak bagi kehidupan masyarakat, baik dampak positif maupun dampak negative (Jannah et al, 2017).

Pembangunan berbasis masyarakat merupakan wacana yang harus dikedepankan guna mencapai keberhasilan pembangunan di berbagai sektor, termasuk sektor pariwisata. Wacana pengembangan Community Base Tourism (CMT) yang saat ini sering dijadikan dasar pengembangan pariwisata baik secara nasional, regional, maupun internasional (Amerta, 2017). Pariwisata berbasis masyarakat identik dengan pembangunan pariwisata berkelanjutan dan sering dikaitkan dengan pariwisata alternatif yang ingin menyeimbangkan antara sumber daya alam, nilai-nilai sosial dan masyarakat, sehingga bermanfaat secara positif bagi masyarakat lokal dan wisatawan.

\subsection{Pemetakan lingkungan internal dan external pengembangan Community Base Tourism (CBT)}

Berdasarkan hasil elaburasi dari setiap permasalahan yang terpotret dari kajian pustaka yang telah dilakukan maka dimensi dalam kajian dibagi menjadi dua yaitu dimensi internal dan eksternal Dalam manajemen strategi dimensi internal terkait dengan kekuatan dan kelemahan, sedangkan dimensi ekternal terkait dengan peluang dan ancaman. dalam implementasi kebijakan CBT terkait Hukum Kepariwisataan di Indonesia. Berikutnya pemataan kedua dimensi tersebut dituangkan dalam matrik EFAS/IFAS (table 1). 
Tabel 1. IFAS/EFAS Matrix

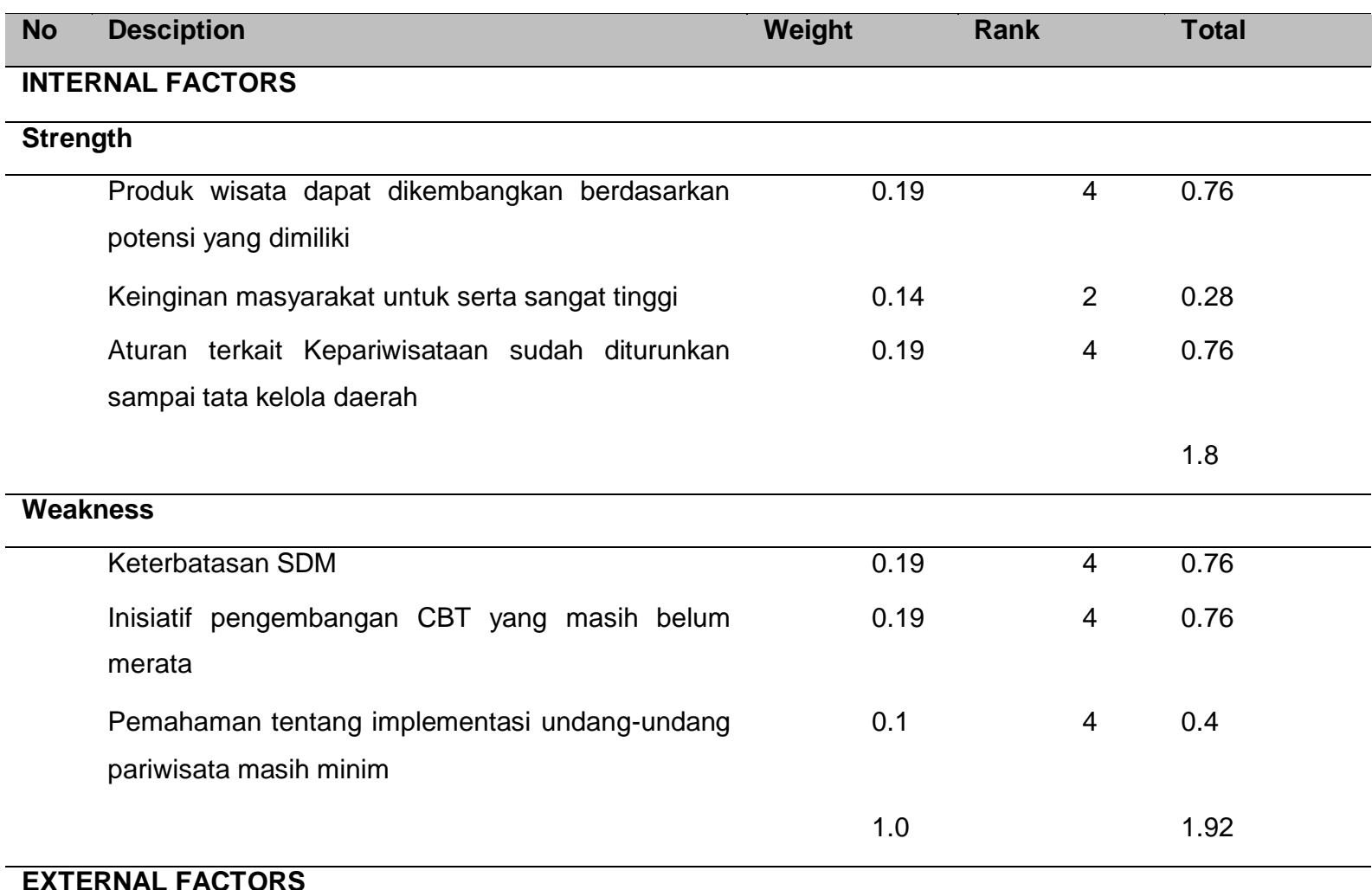

Opportunity

Permintaan wisata berbasis local wisdom cukup

0.15

0.6

tinggi

Perhatian Pemerintah terkait CBT cukup baik

$0.2 \quad 2 \quad 0.4$

Indonesia kaya akan diversity

0.2

$4 \quad 0.8$

1.8

\begin{tabular}{llllll}
\hline Threats & & & \\
\hline $\begin{array}{l}\text { Masuknya investasi dengan modal tinggi dan } \\
\text { dengan tata kelola private company }\end{array}$ & 0.1 & 4 & 0.4 \\
$\begin{array}{l}\text { Banyak pengusaha sektor pariwisata adalah } \\
\text { pejabat negara }\end{array}$ & & & 0.2 & 4 & 0.8 \\
$\begin{array}{l}\text { Arah pengembangan } \\
\text { berkesinambungan }\end{array}$ & CBT belum & 0.15 & 3 & 0.45 \\
& & & & & 1.65
\end{tabular}

Sumber: Hasil Penelitian (2021)

Secara empiric, kepariwisataan di Indonesia khususnya CBT cukup mengkhawatirkan, dimana pada faktor, internal kelemahan lebih mendominasi. Sedangkan pada faktor eksternal, tantangan lebih mendominasi. Secara visual hasil dari EFAS/IFAS dipaparkan dalam Grand Matrix Strategi (Gambar 1). 


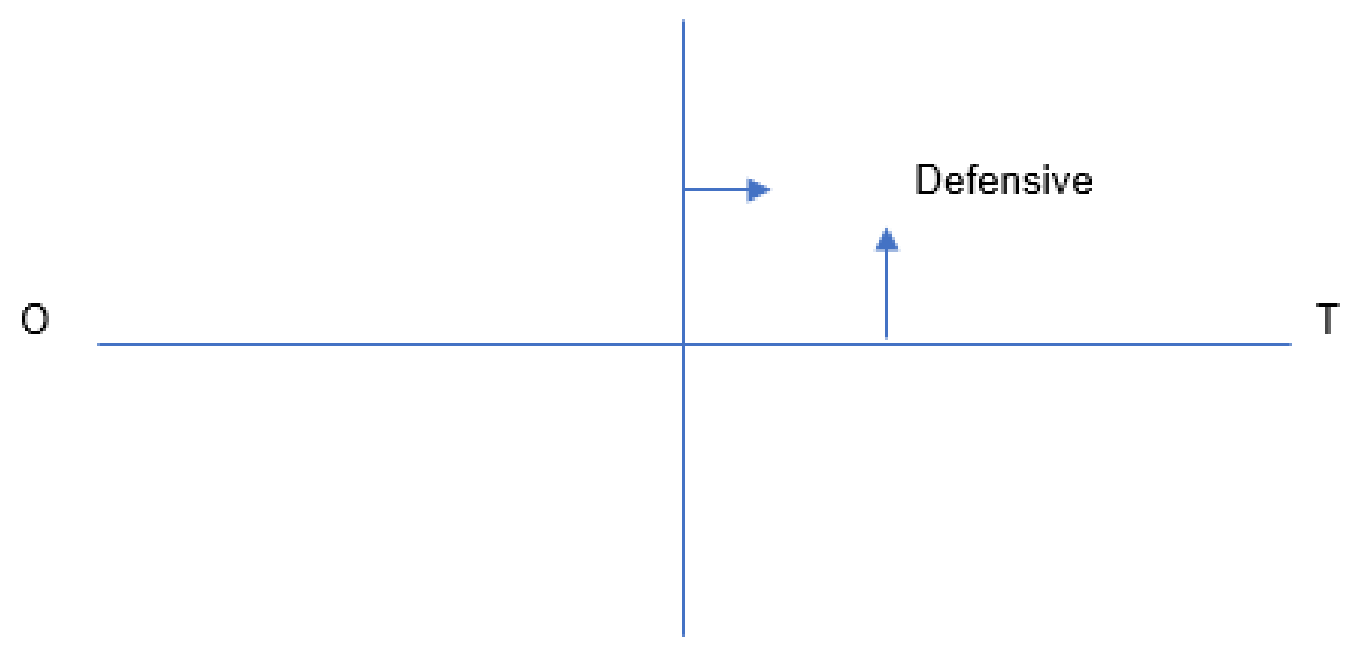

S

Sumber: Hasil Penelitian (2021)

Gambar 2. Grand Matrix Strategy

Berdasarkan gambar 1, posisi kepariwisataan di Indonesia khususnya CBT ada pada posisi defensive, sehingga strategi yang logis untuk dilakukan adalah melakukan integrasi vertical dan diversifikasi konglomerat (Fred, 2008).

\subsection{Strategi pengembangan Community Base Tourism (CBT)}

Peraturan perundang-undangan merupakan faktor yang sangat penting dalam sistem hukum nasional khususnya di Indonesia. Dimana peraturan perundang-undangan merupakan salah satu instrumen yang diyakini sangat efektif dalam pembaharuan hukum (law reform) dikarenakan kekuatnya yang bersifat mengikat dan memaksa. Disinilah pentingnya peranan politik hukum. Pembentukan peraturan perundang-undangan dan hukum nasional sangat dipengaruhi oleh eksistensi politik hukum, karena politk hukum merupakan dasar pedoman dalam proses penentuan nilai-nilai, penetapan, pembentukan dan pengembangan hukum nasional di Indonesia. Suatu mekanisme penciptaan peraturan perundang-undangan salah satunya dibentuk melalui Politik Hukum yang dikendaki para penguasa pada masa tersebut. Melalui politik hukum dapat menentukan arah kebijakan pemerintah.

Kaitannya dalam Hukum Kepariwisataan di Indonesia, berdasarkan hasil pemetaan posisi lingkungan ekternal dan internal dan divisualisasikan dalam Grand Matrik Strategy, maka arah pengembangan CBT adalah menuju pada integrasi vertikal dan diversifikasi konglomerat. Secara umum integrasi vertikal terdiri dari merger lintas sektor komponen (misalnya, antara hotel dan maskapai penerbangan) (Lalerty and Fossen, 2001). Kerjasama antar daerah menjadi semakin penting dengan ditetapkan pengaturannaya yang lebih terperinci di dalam UU No 23/2014 tentang Pemerintah Daerah. Menurut Pasal 364 UU tersebut, kerjasama antar daerah menjadi kewajiban dilaksanakan oleh daerah-daerah yang berbatasan untuk penyelenggaraan 
urusan pemerintahan yang memiliki eksternalitas lintas daerah; dan penyediaan layanan publik yang lebih efisiesn jika dikelola bersama. Salah satu potensi kegiatan kerjasama antar daerah adalah kerjasama dibidang pariwisata. Jenis kerjasama yang dapat dikembangkan ini meliputi kerjasama antar - Daerah provinsi, kerjasama antara daerah provinsi dan daerah kabupaten/kota dalam wilayahnya, kerjasama antara daerah provinsi dan daerah kabupaten/kota dari provinsi yang berbeda, kerjasama antara daerah kabupaten/kota dari daerah provinsi yang berbeda, kerjasama antar-daerah kabupaten/kota dalam satu daerah provinsi.

\section{Kesimpulan}

Pengembangan pariwisata merupakan implementasi dari konsep Sustainable Development. Namun dalam pengembangan pariwisata, masyarakat tidak hanya menjadi penonton atau sekedar pasar yang menjadi objek pemasaran pariwisata, tetapi masyarakat harus memiliki peran dalam pengelolaan pariwisata. Community Base Tourism (CBT) merupakan syarat mutlak dalam mengoptimalkan dampak positif kegiatan pariwisata bagi masyarakat. Hukum ada, untuk menjamin kepastian hukum yang adil dan perlakuan yang sama di depan hukum bagi warganya. Memastikan cita-cita bangsa Indonesia untuk mewujudkan kesejahteraan bagi seluruh rakyat Indonesia dapat terwujud. Hipotesis spekulatif yang dapat disampaikan dalam kajian ini bahwa pengembangan CBT dapat dilakukan dengan dua alternatif strategi, yaitu integrasi vertical dnegan membangun kerjasama dengan wilayah sekitar destinasi dalam usaha menyiapkan membentuk supply demand wisata. Alternatif kedua adalah diversifikasi konglomerat dengan mengoptimalkan potensi yang ada sehingga dapat memetakan target pasar baru. Dalam hal ini kebijakan pemerintah dalam membangun atmosfire wisata yang berpihak pada masyarakat sangat dibutuhkan sebagai implementasi dari UndangUndang Republik Indonesia Nomer 10 tahun 2009 tentang Kepariwisataan dan Peraturan Menteri Dalam Negeri Nomor 33 Tahun 2009 tentang Pedoman Pengembangan Ekowisata di Daerah.

\section{Daftar Pustaka}

Amerta, I Made Suniastha. 2017. Community Based Tourism Development. International Journal of Social Sciences and Humanities. 1(3), p.97-107

Comerio, Niccolò and Strozzi, Fernanda. 2018. Tourism and its economic impact: A literature review using bibliometric tools. Tourism Economics, 25(1),p.109-131. https://doi.org/10.1177/1354816618793762

Dhian, Tyas Untari. 2019. The development strategy of Betawi Eco-Culinary Tourism as a potential business in DKI Jakarta, Indonesia. African Journal of Hospitality, Tourism and Leisure, 8 (Special Edition CUT),p. 1-8 
Dhian, Tyas Untari. Darusman, Dudung. Prihatno, Joko. Arief, Harnios. 2018. Strategi Pengembangan Kuliner Tradisional Betawi di DKI Jakarta. EKUITAS (Jurnal Ekonomi dan Keuangan), 2(3),p.313-340

Dhian, Tyas Untari. 2020. The role of information technology in promotion strategy. Case in taman mini Indonesia indah and ragunan, Indonesia. Journal of Environmental Management and Tourism (JEMT), 11 (04 (44)),p.960-964

Jannah, EU. Muryani, C. Rindarjono, MG. 2017. Community-Based Tourism Development at Gajah Mungkur Wonogiri Tourist Attraction. IOP Conf. Series: Earth and Environmental Science 145. doi :10.1088/1755-1315/145/1/012017

Kurnia, Kamal Fahmi. 2019. Pengaturan Penyelenggaraan Kepariwisataan Dalam Perspektif Negara Kesejahteraan. Doctrinal, 4(1), p.902-916

Lalerty, George and Fossen, Anthony van. 2001. Integrating the tourism industry: problems and strategies. Tourism Management 22 ,p.11-19

Made, Gde Subha Karma Resen. 2015. Pengaturan Badan Usaha Milik Daerah Berdasarkan Good Governance dan Good Corporate Governance. Disertasi. Universitas Gadjah Mada; Yogyakarta.

Martaleni, Martaleni. Hadiyati, Ernani. Pertiwi, Yussi Isna. Yasa, Ni Nyoman Kerti. 2021. Role of tourist motivation as mediating variable on visitor decisions at Indonesian tourism village. Innovative Marketing, 17(3), p.88-98. http://dx.doi.org/10.21511/im.17(3).2021.07

Pawaskar, Pinky. Mekoth, Nandakumar . Thomson, Albino Roshan. 2020. Travel Motivation and Choice of Destination Attributes: Empirical Evidences based on Tourist Perceptions. International Journal of Advanced Science and Technology, 29(8s), p. 634-649

Postma, Albert and Schmuecker, Dirk. 2017. Understanding and overcoming negative impacts of tourism in city destinations: conceptual model and strategic framework. Journal of Tourism Futures. 3(2), p.95-101

Pramanik, Purwanti Dyah. Ingkadijaya, Rahmat, Achmadi, Mochamad. 2019. The Role of Social Capital in Community Based Tourism. Journal of Indonesian Tourism and Development Studies. 7(2).p. 62-73

Shaw, G. and Williams, A.M. (2002). Critical Issues in Tourism: A Geographical Perspective (2nd ed), Blackwell, Oxford.

Stock, M. (2007). European cities: towards a recreational turn?. HAGAR. Studies in Culture, Polity and Identities, 7(1), p. 115-134

Sunuantari, Manik. 2017. Tourism Communication in Community Based Tourism in Dieng Community, Central Java, Indonesia. Binus Business Review, 8(2), p. 149-156. DOI: https://doi.org/10.21512/bbr.v8i2.1894

Tahir Arifin. 2014. Kebijakan Publik dan Transparansi Penyelanggaraan Pemerintah Daerah. CV Alfabeta, Bandung.

Winarno B. 2012. Kebijakan Publik. (Teori, Proses, dan Studi Kasus) CAPS, Yogyakarta. 
Dhoni Martein, Dhian Tyas Untari, Desyana Berliana, Iswiyati Kunti, Tiara Yuliana Wanti, Wiky Rikamza

Zaei, Mansour Esmaeil. Zaei, Mahin Esmaeil. 2013. THE IMPACTS OF TOURISM INDUSTRY ON HOST COMMUNITY. European Journal of Tourism Hospitality and Research, 1(2), p.12-22

http://www.pustakaborneo.org/esd-sdgs/esd/3-pilar-pembangunanberkelanjutan.html\#gsc.tab=0, diakses 3 Desember 2021 